\title{
Strategi Penanaman Toleransi Beragama Anak Usia Dini
}

\author{
Anwar Zain \\ Universitas Muhammadiyah Banjarmasin \\ anwarzain991@gmail.com \\ DOI: $10.31849 /$ paud-lectura.v\%vi\%i.4987 \\ Received 29 September 2020, Accepted 22 September 2020, Published 1 Oktober 2020
}

\begin{abstract}
Abstrak:
Sekolah PAUD Widya Dharma merupakan satu satunya lembaga pendidikan tingkat TK (Taman Kanak-Kanak) yang mempunyai siswa yang berlatar berlakang agama lebih beragam dari PAUD lainnya di Kota Banjarmasin, meliputi: Islam, Kristen, Katolik, Budha dan Hindu. Persentasi siswa dari beragam agama tersebut tidak ada jumlah siswa dari beragama yang mendominasi lebih dari 50\%. Secara urutan kuantitas jumlah siswa berdasarkan latar belakang agama terbanyak ialah (1) Kristen Protestan, (2) Islam, (3) Katholik, (4) Budha, dan (5) Hindu. Berdasarkan latar belakang singkat tersebut, maka sangat perlu dan manfaat secara kajian ilmiah untuk diteliti tentang kehidupan toleransi beragama anak dengan anak lainnya yang mempunyai agama berbeda-beda ditingkat PAUD. Oleh karena itu, tujuan penelitian untuk melihat strategi penanaman toleransi beragama anak di PAUD Widya Dharma Kota Banjarmasin. Pendekatan Penelitian menggunakan metode penelitian kualitatif yang dilakukan dengan penelitian lapangan, informan dalam menggali penelitian ditujukan kepada guru-guru agama. Teknik pengumpulan data adalah wawancara, observasi dan dokumentasi. Kemudian untuk memvalidasi tingkat kebenaran data tersebut maka dalam hal ini menggunakan teknik triangulasi metode dan sumber. Hasil penelitian menyatakan bahwa strategi penanaman toleransi beragama pada anak usia dini melalui 5 (lima) kegiatan, yaitu (1) Guru mengenalkan sifat-sifat baik. (2) Guru mengenalkan sifat toleransi beragama. (3) Guru memberikan stimulus agar anak berpikir tentang sifat-sifat baik, 4) Guru memberikan stimulus agar anak berpikir tentang toleransi beragama. (5) Guru membuat anak merasakan manfaat sifat toleransi beragama.
\end{abstract}

Kata kunci: Strategi Penanaman, Toleransi Beragama, Anak Usia Dini.

\section{Abstract:}

PAUD Widya Dharma School is the only kindergarten level educational institution (Kindergarten) which has students with more diverse religious backgrounds than kindergarten schools. Other PAUD in Banjarmasin City. The students' religious backgrounds include: Islam, Christianity, Catholicism Buddhism and Hinduism. The percentage of students from various religions does not have the number of students from that religion which dominates more than 50\%.. In order of quantity, the highest number of students based on religious backgrounds is (1) Protestant Christianity, (2) Islam, (3) Catholic, (4) Buddhist, and (5) Hinduism. Based on this brief background, it is very necessary and beneficial in a scientific study to study the religious tolerance of children 
with other children who have different religions at the kindergarten level. PAUD. Therefore, the researcher focuses this research on the strategy of internalization children's religious tolerance in PAUD Widya Dharma Banjarmasin City. The research approach used qualitative research methods carried out by field research, informants in exploring research aimed at religious teachers, and the object of this study was to find out how to cultivate religious tolerance strategies for children of different religions. The research technique is by conducting interviews, observation and documentation. Then to validate the level of correctness of the data, in this case using the triangulation technique methods and sources. The results of the study state that the strategy of internalization religious tolerance in early childhood through 5 (five) activities, namely: (1) The teacher introduces good traits, (2) The teacher introduces the nature of religious tolerance; (3) The teacher provides a stimulus so that the child thinks about good traits; (4) Tthe teacher provides a stimulus so that the child thinking about religious tolerance, (5) Teachers make children feel the benefits of religious tolerance.

Keywords: Strategy of Internalization, Religious Tolerance, Early Childhood

\section{PENDAHULUAN}

Manusia merupakan makhluk hidup yang sangat berbeda dibandingkan ciptaan Tuhan lainnya dimuka bumi ini. Manusia mempunyai kelebihan yang tidak dimilki oleh makhluk lainnya yaitu bentuk fisik yang bagus (jasmani) dan akal yang potensial (rohani). Dua kelebihan yang ada pada diri manusia itu yang menyebabkan manusia mempunyai kualitas dibandingkan makhluk atau ciptaan Tuuhan lainnya sebagai alat untuk mengembangkan diri dan mengelola alam ini agar manusia mempunyai peradaban yang berkembang.

Eksisistensi manusia lebih utama daripada makhluk lainnya tersebut sangat ditentukan oleh faktor akal yang sehat, karena dengan akal sehatlah manusia dapat berpikir untuk mengatur diri dan orang lain serta alam semsta ini. Oleh karena itu, akal yang sehat yang dimiliki manusia merupakan tanda penciptaan manusia itu sebaik-baik penciptaan oleh Tuhan, yang Alah nyatakan pada surah At-Tin ayat 4.

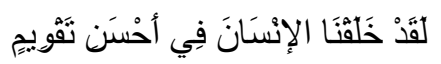

"Sesungguhnya Kami telah menciptakan manusia dalam bentuk yang sebaikbaiknya" (Kemenag, 2010: 597).

Berdasarkan ayatal-Qur'an di atas bahwa setiap manusia dijadikan dengan keadaan yang mempunyai bawaan yang baik atau disebut juga dengan Fithrah. Menurut Quraish (1996: 284) bahwa fithrah manusia merupakan kejadiannya sejak semula atau aspek bawaan yang memang ada dalam diri manusia dari lahirnya. Manusia dari kejadiannya membawa aspek potensi beragama yang lurus, yaitu keinginan manusia yang bertuhan dengan konsep tauhid, yang Allah tegaskan didalam al-Qur'an pada surah ar-Rum ayat 30 .

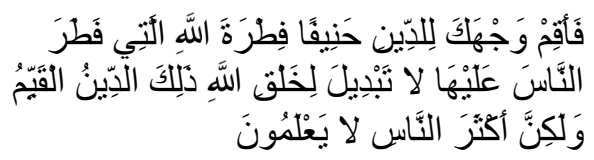

"Maka hadapkanlah wajahmu dengan Lurus kepada agama Allah; (tetaplah atas) fitrah Allah yang telah menciptakan manusia menurut fitrah itu. tidak ada peubahan pada fitrah Allah. (Itulah) agama yang lurus; tetapi kebanyakan manusia tidak mengetahui” (Kemenag, 2010: 407). 
Setiap manusia mempunyai modal bawaan diri yang dianugerahi oleh Allah SWT. Diantara modal bawaan itu ialah rasa keberagamaan. Oleh karena itu, pada diri setiap anak mempunyai bawaan potensi atau disebut didalam agama dengan istilah fithrah. Dalam hal ini berarti anak mempunyai fithrah keinginan beragama, sebagaimana sabda Nabi Muhammad SAW.

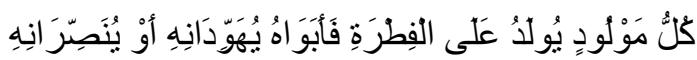

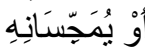

"Setiap anak dilahirkan dalam keadaan fithrah. Kemudian kedua orang tuanyalah yang akan menjadikan anak itu menjadi Yahudi, Nashrani atau Majusi" (Bukhori, 2010: 1296).

Berdasarkan hadits di atas, bahwa setiap anak mempunyai keperluan untuk diajar dan didik tentang agama dengan cara agama, serta setiap anak mempunyai potensi untuk mau mengamalkan agama tersebut.

Anak usia dini merupakan fase anak yang fithrah, dalam artian anak pada masa ini mereka memerlukan bantuan orang disekitarnya untuk mengembangkan semua potensi fithrahnya. Potensi anak usia dini meliputi; aspek nilai agama-moral, fisikmotorik, kognitif, sosial-emosional, bahasa dan seni. Anak usia dini berdasarkan pertumbuhan dan perkembangannya terbagi menjadi 4 (empat) tingkatan berdasarkan usia anak, yaitu (1) Fase bayi dari lahir sampai 12 bulan, (2) Fase toddler (batita) usia 1-3 tahun, (3) Fase prasekolah usia 3-6 tahun, dan (4) masa sekolah awal (sekolah dasar) 6-8 tahun. Perkembangan anak usia dini harus diorientasikan kepada penanaman dasar-dasar kehidupan secara komfrehensif bagi anak, yaitu terpenuhinya pengembangan nilai agama-moral, kognitif, sosial- emosional, fisik-motorik, bahasa dan seni yang seimbang sebagai dasar pembentukan pribadi yang utuh (Hartoyo, 2004: 3).

Tujuan PAUD pada hakikatnya ialah untuk mengembangakan aspekaspek potensi yang ada pada diri anak, pada pasal 28 UU nomor 20 tahun 2003 tentang Sistem Pendidikan Nasional ditegaskan ada empat unsur yang harus dipenuhi dalam mengembangkan perkembangan AUD, yaitu (1) Pembinaan AUD harus dilakukan pembinaan kepada anak sejak lahir sampai dengan usia 6 (enam) tahun. (2) Pengembangan AUD dilakukan melalui stimulusisasi (proses rangsangan) pembelajaran. (3) Pendidikan AUD bertujuan agar membantu pertumbuhan dan perkembangan jasmani dan rohani secara menyeluruh. (4) Proses pendidikan di PAUD ialah persiapan untuk memasuki pendidikan lebih lanjut (Sekolah Dasar).

Pendidikan pada saat anak berusia 0-6 taun (AUD) mempunyai manfaat luar biasa dibandingkan usia anak yang sudah mulai dewasa terkhusus pada aspek pembentukan sikap/perilaku. Sebagaimana pendapat Mansur (2011: 18) bahwa "pendidikan anak usia dini yang ditanamkan sejak dini merupakan memiliki kelebihan dibandingkan dengan pendidikan yang ditanamkan selain pada usia ini".

Lembaga PAUD merupakan pendidikan sekolah tahap awal sebelum lembaga SD (Sekolah Dasar), tetapi tidak semua anak Indonesia sebelum masuk pada pendidikan SD mereka belajar di PAUD. Karena lembaga PAUD adalah pendidikan yang tidak bersifat wajib untuk syarat anak memasuki jenjanng pendidikan SD, tetapi secara tujuan utama pendidikan 
PAUD adalah untuk mengembangkan potensi anak agar mempunyai kesiapan untuk memasuki jenjang pendidikan selanjutnya. Hal ini sesuai dengan Pasal 1 butir 14, UU No. 20 Tahun 2003 bahwa "Pendidikan anak Usia Dini (PAUD) adalah suatu upaya pembinaan yang ditujukan kepada anak sejak lahir sampai dengan usia 6 tahun yang dilakukan melalui pemberian rangsangan pendidikan untuk membantu pertumbuhan dan perkembangan jasmani dan rohani agar anak memiliki kesiapan dalam memasuki pendidikan lebih lanjut" (Dpdikbud, 2003: 100) .

Dalam mendidik dan mengembangkan sifat dan perilaku keberagamaan anak tingkat usia dini maka perlu didirikan lembaga formal seperti sekolah TK (Taman Kanakkanak), KB (Kelompok Bermain) dan TPA (Tempat Penitipan Anak). Oleh karena itu, harus mengacu dan berpedoman pada kurikulum PAUD 2013 yang dijabarkan dalam Permendikbud. No. 137 dan No. 146. 2014 tentang Kurikulum PAUD 2013, didalamnya memuat Kometensi Inti (KI) dan Kompetensi Dasar (KD) tentang aspek Spritual dan Sosial-Emosional yang berkaitan tentang pengembangan keagamaan. Adapun KI/KD yang didalamnya tentang pengembangan nilainilai keagamaan dan sifat toleransi beragama yaitu: (1) KD.1.1. Mempercayai adanya Tuhan dengan perantara apa diciptakan-Nya. (2) KD.3.1.Mengenal rutinitas kegiatan ibadah agama. (3) KD.4.1.Melakukan kegiatan beribadah sehari-hari dengan tuntunan orang dewasa. (4) KD.1.2. Menghargai diri sendiri, orang lain, dan lingkungan sekitar sebagai rasa syukur kepada Tuhan. (5) KD.2.10. Memiliki perilaku yang mencerminkan sikap menghargai dan toleran kepada orang lain. (Permendikbud, 2015: 6-8)

Perilaku toleransi antar sesama merupakan suatu keniscayaan yang tidak bisa kita hindari. Karena kita hidup ditengah bermacam ragam perbedaan agama, ras, suku dan lainnya. Maka harus ditanamkan bahwa persaudaraan itu harus dihargai dengan bentuk saling menghormati perbedaan. Dengan demikian, kita harus lebih pada keterlibatan aktif umat terhadap kenyataan toleran dan setiap umat beragama dapat berinteraksi positif dalam lingkungan kemajemukan. Sehingga umat beragama bersedia menerima kenyataan pendapat yang berbeda-beda tentang kebenaran yang dipegang, dpat menghargai aqidah orang lain terhadap agama yang dijalaninya, serta memberikan kebebasan untuk menjalankan apa yang dipeluknya dengan wujud perilaku agar tidak bersikap mencela dan memusuhinya. (KBBI, 2003: 1065)

Semua agama mengajarkan yang namanya toleransi beragama, karena semua agma sangat menghargaia adanya sebuah perbedaan bagi seseorang untuk memilih dan menentukan apa agama yang dianutnya. Agama mayoritas di Indonesia ialah agama Islam. Islam sangat mengakui sifat dan sikap toleransi dengan agama lainnya. Toleransi dalam Islam diantaranya dijelaskan dalam firman Allah Surah Hud ayat 118-119:

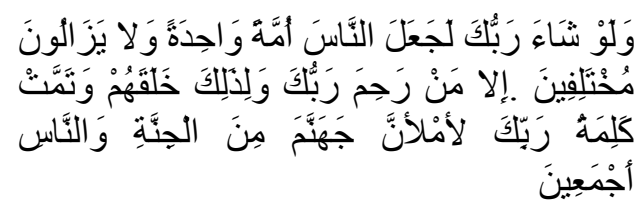

"Jikalau Tuhanmu menghendaki, tentu Dia menjadikan manusia umat yang satu, tetapi mereka Senantiasa berselisih pendapat, kecuali orang-orang yang diberi rahmat oleh Tuhanmu. dan untuk 
Itulah Allah menciptakan mereka. kalimat Tuhanmu (keputusan-Nya) telah ditetapkan: Sesungguhnya aku akan memenuhi neraka Jahannam dengan jin dan manusia (yang durhaka) semuanya. (Kemenag, 2010: 235)

Kemudian surat Al-Hujurat ayat 13 menjelaskan tentang larangan agar tidak merendahkan orang lain agar selalu bisa bertoleransi.

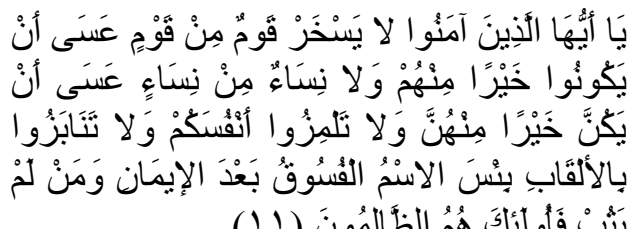

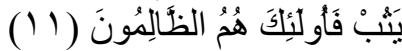

"Hai orang-orang yang beriman, janganlah sekumpulan orang laki-laki merendahkan kumpulan yang lain, boleh Jadi yang ditertawakan itu lebih baik dari mereka. dan jangan pula sekumpulan perempuan merendahkan kumpulan lainnya, boleh Jadi yang direndahkan itu lebih baik. dan janganlah suka mencela dirimu sendiri dan jangan memanggil dengan gelaran yang mengandung ejekan. seburuk-buruk panggilan adalah (panggilan) yang buruk sesudah iman dan Barangsiapa yang tidak bertobat, Maka mereka Itulah orang-orang yang zalim”. (Kemenag, 2010: 5)

Agama Kristen adalah agama terbesar setelah agana Islam, dalam ajaran Kristen mengakui toleransi dalam perbedaan umat beragama harus tetap terjaga secara harmonis. Sebagaimana berbagai agama mengajarkan tentang toleransi begitu juga dalam agama Budha mengajarkan para pemeluknya untuk menjunjung tinggi toleransi dengan orang yang berbeda agama. Hal ini terdapat dalam perintah kitab suci agama Budha.

(Sutta, 2009: 77)

Indonesia ialah negara penduduk muslim terbanyak diduia dan warganya mayoritas Islam, tetapi Indonesia bukan negara Islam dengan menggunakan syariat Islam sebagai satu-satunya dasar hukum dalam menjalankan pemerintahan. Indonesia sangat kaya dengan perbedaan, baik perbedaan suku, ras, budaya, bahasa, kepercayaaan dan agama. Dasar negara Indonesia sangat memberikan kebebasan dalam beragama, yaitu Pancasila. Pancasila memberikan ruang agama saja yang ingin di anut warganya baik itu agama Islam, Kristen Protestan, Katolik, Budha, Hindu, Konghucu dan berbagai kepercayaan yang selalu terpelihara di bawah naungan dasar Pancasila.

Agama mempunyai peranan penting dalam kehidupan masyarakat. Karena pada dasar negara atau ideologi negara sangat jelas meletakkan nilai-nilai keagamaan pada sila pertama pancasila "Ketuhanan Yang Maha Esa". Tidak hanya agama Islam, agama lainnya juga berperan dan berpengaruh secara bersama-sama pada aspek politik, ekonomi dan budaya bahkan terhadap pendidikan. Dalam UUD 1945 dinyatakan bahwa "tiap-tiap penduduk diberikan kebebasan untuk memilih dan mempraktikkan kepercayaannya" dan "menjamin semuanya akan kebebasan untuk menyembah, menurut agama atau kepercayaannya", dan juga berdasarkan UU PNPS Pasal 1 No. 1 Tahun 1965 menyatakan bahwa Pemerintah secara resmi mengakui enam Agama, yakni Islam, Protestan, Katolik, Hindu, Budha dan Khonghucu. 
Ppemerintah sudah berusaha dalam menciptakan dan membangun kondisi warga masyarakat beragama yang harmonis yang telah dilakukan dari berbagai program, diantaranya ialah mendirikan berbagai lembaga dan instansi yang tugasnya untuk mengurusi permasalahan-permasalahan antar umat/warga beragama. Selain itu, tentunya yang lebih efektif dalam melestarikan dan mengembangkan kehidupan yang harmonis antar ummat beragama ialah melalui penanaman nilainilai dengan jalan lembaga pendidikan baik formal, informal maupun non formal. Pada lembaga inilah dilakukan penanaman nilai-nilai toleransi yaitu dengan kebersamaan, saling menghormati, inklusifisme, kerukunan antar umat beragama. Harapannya ketika mulai dari anak usia dini sudah ditanamkan dan dibiasakan dengan toleransi, maka akan menjadi "mindset" cara berpikir bahkan cara pandang hidup merka yang akan sulit untuk hilang dan terhapus.

Pemerintah seyogianya menaruh perhatian yang lebih kepada upaya penanaman nilai-nilai toleransi, khususnya melalui jenjang pendidikan. Jenjang pendidikan yang dimaksudkan tidak hanya pada jenjang pendidikan tinggi, tetapi akan lebih maksimal manakala sudah dimulai sejak usia dini (Zaini, 2010: 1).

Aspek pengembanagan agama anak usia dini selain bidang ibadah ada juga sifat keagamaan yang harus dimiliki oleh anak, yaitu sifat toleransi beragama. Guru harus mengembangkan nilai-nilai toleransi bagi anak, baik toleransi secara perbedaan apapun, termasuk toleransi berbeda agama. Toleransi sifatnya abstrak juga sama halnya dalam menanamkan ibadah kepada Tuhan, oleh karenanya, dalam menanamkan sifat toleransi beragama pada anak usia dini harus memerlukan strategi pembelajaran yang tepat juga agar anak secara proses perkembangannya terbiasa dengan perbedaan sebagai respon toleransi.

Kepala Sekolah TK. PAUD Widya Dharma Kota Banjarmasin merupakan sekolah tersebut berbasis pancasila, yang mana semua anak beragama apapun boleh belajar di sekolah ini. Sekolah ini satu-satunya sekolah tingkat PAUD yang mempunyai siswa yang beragam atau multi agama, meliputi: agama Islam, Kristen, Katolik dan Budha. Prosentasi siswa dari beragam agama tersebut tidak ada jumlah siswa dari beragama yang sama mendominasi lebih dari 50\%. Prosentasi siswa berdasarkan agamanya yaitu agama Kristen Protestan 43\% (41 siswa), agama Islam 23\% (21 siswa), agama Katholik 19\% (18 siswa), agama Budha 14\% (13 siswa), dan agama Hindu 1\% (1 siswa).

Proses pembelajaran di PAUD Widya Dharma ini ketika memulai pelajaran anak-anak disuruh untuk berdo'a, kemudian semua anak berdo'a dengan cara berdo'a menurut agamanya masing-masing dengan tertib. Kemudian ada kejadian menarik ketika berdo'a bersama untuk memulai pembelajaran, ada anak yang beragama islam mengikuti cara berdo'a temannya yang beragama kristen, lalu temannya yang kristen ini menegur kepada anak beragama islam ini, bahwa cara berdo'a agama islam itu mengangkat tangan dan membukanya.

Setiap hari sabtu anak-anak PAUD Widya Dharma ini diberikan pelajaran agama oleh masing-masing guru yang seagama, meliputi pembelajaran cara berdo'a, sembahyang dan bacaan puji-pujian/dzikir/salam. Dalam kegiatan proses pembelajaran 
agama tersebut anak-anak dengan semangat dan gembira mengikutinya, dan para guru agamanya juga membangun suasana yang menyenangkan dalam mengajarkan materi agamanya. Kemudian ketika guru agama mengenalkan rumah ibadah atau tempat ibadah agama, maka guru tersebut tidak menjelaskan secara lisan saja, tetapi diawali dengan menunjukkan gambar-gambar rumah ibadah, dan gambar rumah/tempat ibadah tersebut tidak hanya mengenalkan satu agama yang dianut oleh kelas itu saja, tetapi semua rumah dan tempat ibadah agama yang lainnya juga dikenalkan. Berdasarkan fenomena di atas, maka menurut peneliti hal ini sangat menarik untuk diteliti dengan tujuan penelitian untuk mengetahui apa saja strategi penanaman toleranasi beragama kepada anak usia dini dengan berbagai macam agama dengan temannya.

\section{METODOLOGI PENELITIAN} penelitian ini menggunakan Pendekatan metode kualitatif yang dikatagorikan dalam bidang keilmuan sosial (social science) yang secara prinsip implementasinya berdasarkan observasi langsung peneliti dengan objek yang diteliti dengan konteks bahasa dan kultur sesuai tempat yang diteliti (Moleong, 2002: 3). Penelitian ini jenisnya ialah penelitian lapangan (field research), yang mana tujuannya untuk menggali dan mendalami tentang objek sosial dalam hal ini ialah objek lingkup pendidikan secara utuh dan menyeluruh sehingga dapat menghasilkan sebuah kajian ilmiah yang terorganisir (Azwar, 2010: 8). Adapun informan untuk menggali objek penelitian ialah semua guru agama dan pejabat dan orang yang terkait dalam penggalian dan pembuktian data penelitian, yaitu 1 guru agama Islam, 2 guru agama Kristen, 1 guru agama Katolik dan 1 guru agama Budha.
Sedangkan objek penelitian ini adalah strategi penanaman toleransi beragama pada anak usia dini. Sumber data dalam penelitian bersumber dari informan, dan dokumentasi. Teknik yang digunakan dalam pengumpulan data penelitian yaitu dengan melakukan wawancara (interview), observasi dan dokumentasi. Dalam menganalisis data yang telah terkumpul menggunakan analisis Milles dan Hubberman (2005: 18) yang berkaitan dengan strategi penanaman toleransi beragama pada anak usia dini dengan cara reduksi data, penyajian data dan menarik kesimpulan. Validasi atau pengecekkan keshahihan data menggunakan triangulasi dari teknik wawancara, observasi dan dokumentasi. Triangulasi adalah teknik dalam barometer tingkat kekuatan dari kebenaran suatu hasil informasi dan data sebagai pembanding. Oleh karena itu, validasi data menggunakan triangulasi sumber dan triangulasi teknik. (Moleong, 2002: 330). Triangulasi sumber ialah teknik validitas yang duganakan dalam menggali suatu kebenaran informasi dengan mewawancarai kepada beberapa orang harus lebih dari satu kepada pihak yang terkait. Dengan demikian triangulasi sumber menggunakan sumber yang berbeda dengan teknik pengumpulan data yanga sama. Kemudian triangulasi teknik merupakan teknik validitas yang digunakan untuk menggali informasi, data dan fakta dari sumber yang sama tetapi teknik pemgumpulan datanya berbeda-beda agar menjadi bahan validasi yang akan menjadi ukuran kepercayaannya tersebut kuat (Nasution, 2003: 115).

\section{HASIL DAN PEMBAHASAN}

Toleransi beragama yang ditanamkan pada anak sejak usia dini sangat penting, karena dengan anak kenal danmengerti tentang toleransi 
sebagai pedoman bersikap dan bertingkah laku dalam kehidupan anak shari-hari (Zaini (2010: 7). Hal ini menunjukkan bahwa peran sekolah sangat urgen dalam menanamkan nilainilai sifat toleransi kepada anak sejak usia dini yang berkelanjutan dengan mengembangkan sifat saling pengertian dan rasa memiliki terhadap umat agama lain.

Dalam implementasi penanaman toleransi terhadap anak dengan anak lainnya sebaiknya pihak sekolah memperhatikan langkah-langkah sebagai berikut: pertama, sekolah membuat dan menerapkan tata tertib mandiri berbasis kearifan lokal. Kedua, para guru harus selalu memberikan nasehat dan penjelasan tentang keniscayaan hidup dengan orang yang berbeda agama disekitar kita.. Ketiga, kurikulum dan buku-buku pelajaran yang digunakan harus multikultural yang memuat nilainilai pluralisme dan toleransi keberagamaan. (Yaqin, 2005: 62-63).

Strategi pembelajaran dalam menenanamkan toleransi beragama di PAUD Widya Dharma Kota Banjarmasin melalui beberapa kegiatan, yaitu (1) Mengenlakan sifat-sifat baik secara umum. (2) Mengenlkan sifat toleransi beragama. (3) Membuat anak berpikir/paham dengan sifat-sifat baik. (4) Membuat anak berpikir tentang sifat toleransi beragama dengan cara anak distimulusi agar menanggapi atau berbiacara. (5) Membuat anak bisa merasakan manfaat sifat toleransi beragama. Temuan tersebut sejalan dengan Pedoman Direktoral Jenderal PAUD (2015: 24) bahwa ada 5 (lima) langkah yang perlu diperhatikan dalam menanamkan sikap pada anak, yaitu anak dikenalkan dengan perilaku dan nilai yang baik dan seharusnya (knowing the good), anak diajak membahas untuk memikirkan dan mengerti mengapa ini baik dan itu tidak baik (thinking the good), anak diajak merasakan manfaat bila perilaku baik itu diterapkan (feeling the good), anak diajak melakukan perilaku yang baik (acting the good), anak dibiasakan untuk menerapkan sikap baik dalam setiap kesempatan (habituating the good).

1) Guru Mengenalkan Sifat-Sifat Baik

Dalam menanamkan sifat toleransi secara umum di PAUD Widya Dharma terlebih dahulu dengan mengenalkan sifat-sifat baik kepada anak dengan cara pembiasaan, nasehat pada kejadian insidentil dan pemberian nasehat pada saat pelajaran agama di kelas agama dan di kelas umum. Hal ini menunjukan bahwa, para guru dalam mengenalkan sifat toleransi beragma terlebih dahulu mengenalkan sifat-sifat baik secara umum kepada anak agar anak mengenal mana sifat yang baik yang harus dilakukan dan mana sifat yang tidak baik yang harus ditinggalkan. Mengealkan sifat-sifat baik dengan cara pembiasaan yaitu para guru melakukan pembiasan-pembiasaan yang dilakukan setiap hari anak, seperti; berdo'a, membuang sampah pada tempatnya dan saling berbagi serta menolong temannya. Temuan ini mendukung hasil penelitian Kutsianto (2014) kegiatan rutinitas yang dilakukan anak usia dini setiap hari dengan cara pembbiasaan melakukan nilai-nilai kegiatan agama, maka akan membentuk karakter anak. Hal ini juga sesuai dengan hasil penelitian Nurul dkk., (2015) bahwa terbiasanya anak usia dini dibimbing oleh guru dengan menaati tata tertib disekolah, maka anak akan bisa berperilaku tertib Mengealkan sifatsifat baik dengan cara pemberian nasehat kepada anak baik secara langsung (sengaja) atau dengan pemberian nasehat pada saat pembelajaran tentang mana 
sifat baik yang harus dilakukan dan mana sifat buruk yang harus ditinggalkan. Dan ada juga pemberian nasehat yang sifatnya insidentil yaitu ketika ada kejadian yang dialami anak, dengan kejadian itu anak bisa tahu mana yang baik dan yang tidak baik. Tindakan insidentil atau spontanitas dalam menegeur dan menasehati anak biasanya dilakukan pada saat guru mengetahui perilaku anak yang kurang baik, seperti anak yang menggunakan tangan kirinya untuk menerima pemberian orang lain atau anak menyerahkan/memberikan Sesutu dengan tangan kiri dengan temannya.. Apabila guru melihat perilaku yang demikian, hendaknya secara spontan diberikan pengertian dan diberitahu bagaimana perilaku yang sepantasnya. Misalnya kalau menerima atau memberikan sesuatu harus tangan kanan kemudian ucapkan terima kasih kepada temannya. (Badru, 2010: 8).

2) Guru Mengenalkan Sifat Toleransi Beragama

Cara guru dalam mengenalkan sifat toleransi beragama kepada anak di PAUD Widya Dharma melalui pembiasaan dan nasehat. Pembiasaan yang dilakukan anak agar terbiasa dengan toleransi beragama adalah dengan berdo'a bersama dengan sikap berdo'a masing-masing sesuai agama yang dianut anak, saling tolong menolong, saling membantu dan saling berbagi ketika anak mempunyai makanan lebih kepada teman-temannya. Dan cara lainnya ialah para guru memberikan nasehat kepada anak agar selalu menghargai temannya berbeda agama saat berdo'a sikap berdo'anya berbeda, jangan ada saling mengejek atau mengolok-olok karena perbedaan fisik. Temuan di atas mendukung hasil penelitian oleh Wulan (2015) bahwa cara untuk menanamkan nilai-nilai toleransi beragama pada anak di sekolah yaitu dengan cara pembiasaan saling tolong menolong tanpa membedakan latar belakang agama. Dan juga mendukung dengan hasil penelitian Dwi (2015) menyatakan bahwa penanaman nilai-nilai agama pada anak di sekolah dengan metode pembiasaan dan metode nasehat. Perbedaan penampilan berpakaian dan bersikap do'a oleh guruguru PAUD Widya Dharma juga merupaka cara dalam mengenalkan anak tentang toleransi beragama kepada orang yang berbeda agama. Para guru di sekolah ini menampilkan sifat toleransi dengan saling menolong dan saling berteman tanpa ada membedakan. Ini merupakan suatu keteladanan yang ditampilkan oleh guru kepada anak-anak. Temuan di atas menguatkan hasil penelitian Hasil penelitian Candra (2015) bahwa ada 2 (dua) faktor pendukung dalam meningkatkan kerukunan anak yang berbeda agama, yaitu pertama keteladanan dari guru dan pihak sekolah yang saling bersikap toleransi. Kedua, tersedianya sarana-prasana yang mewadahi masing-masing agama serta program yang menjunjung kerukunan anatar anak yang berbeda agama. Cara mengenalkan anak terhadap sifat toleransi juga bisa dengan merancang pembuatan RKH (Rencana Kegiatan Harian) yang dalamnya memuat unsur kegiatan anak bisa mengenal toleransi antar agama. Hal ini mendudkung dengan hasil penelitian Santi (2014) bahwa upaya guru dalam mengembangkan sikap toleransi terhadap anak usia dini melalui pendidikan multikultural yang tetuang dalam perangkat pembelajaran. Dalam strategi pemebelajaran untuk menenamkan sikap atau moral kepada anak tidak bisa dengan cara pemberian pemahaman pengembangan kognitif. Karena pengembanag aspek sikap adalah pembentukan kepribadian bukan pengembangan intelektual. Teori ini 
digagas oleh Mc. Paul yang melahirkan strategi pembelajaran apektif konsiderasi. Strategi ini bertujuan untuk bisa membuat anak merasa peduli atau simpati dengan orang lain. Dalam konteks PAUD, anak harus dibiasakan merasakan apa yang dirasakan temannya, misalnya ketika temannya tidak membawa bekal makan, maka anak yang lain harus dibiasakan berbagi kepada temannya. Dengan demikian, pengembangan atau pembelajaran sikap dalam hal ini toleransi beragama pada dasarnya membantu anak bisa mengembangkan kemampuan hidup bersama dengan orang disekitarnya dengan berbagai perbedaan termasuk dalam berbeda agama.

Implementasi strategi pembelajaran model konsiderasi ini dapat dilihat pada langkah-langkah berikut: (1) Berikan suatu masalah berisi konflik yang biasa terjadi dikehidupan sehari-hari kepada anak. Ciptakan situasi "seandainya anak ada dalam posisi masalah tersebut". (2) Mengarahkan siswa agar bisa menganalisis masalah tersebut dengan melihat yang tampak dan yang tersirat, misalnya perasaan, keperluan dan kepentingan orang lain. (3) Menyuruh anak untuk menuliskan atau menyampaikan tanggapannya terhadap masalah tersebut. Hal ini bertujuan agar anak dapat menelaah perasaannya sendiri sebelum ia mendengar respon orang lain untuk dibandingkan. (4) Mengajak siswa untuk menganalisis respon temannya. (5) Mendorong anak untuk berpikir kemudian menyampaikan dampak atau konsekuensi dari setiap respon dan gagasan yang disampaikan temannya terhadap masalah tersebut. Guru harus memberikan ruang untuk anak berargumentasi terhadap gagasan yang disampaikannya serta saling menghargai pendapat teman. (6) Membuat anak untuk membuka pandangan dari sudut pandang agar menambah wawasan anak dapat menilai sikap dan perilakunya apakah sesuai dengan nilai yang dimilikinya. (7) Memobilisasi agar anak dapat merumuskan sendiri tindakan yang harus dilakukan sesuai dengan pilihannya berdasarkan dari pertimbangan diri sendiri. Sedangkan guru jangan menilai benar atau salah atas pilihan anak, tetapi guru lebih mengarahkan anak untuk bisa mereka menentukan sendiri pilhan yang lebih matang menurut dirinya sendiri (Sanjaya, 2008: 278).

3) Guru Membuat Anak Mengerti Sifat-Sifat Baik

Membuat anak agar bisa berpikir dalam artian mengerti dengan sadar akan sifat toleransi di PAUD Widya Dharma terlebih dahulu mengenalkan secara umum mana saja sifat yang baik yang harus dilakukan dan mana saja sifat yang tidak baik yang harus tidak dilakukan. Cara mengenalkan sifat baik dan sifat tidak baik agar anak bisa berpikir dan mengerti diantaranya pada saat pembelajaran anak disajikan gambargambar contoh yang menggambarkan perilaku dan sifat yang merangsang anak untuk berpikir menyimpulkan mana yang baik dan mana yang tidak baik. Hal ini menunjukkan bahwa guru dalam mengenalkan sifat baik dan sifat tidak baik dengan pengmatan objek konkret dalam bentuk gambar dengan cara belajar anak menjadi mudah, karena anak disajikan dengan benda konret atau benda miniatur yang mewakili benda aslinya. Cara lain untuk bisa menstimulasi anak bisa berpikir sifat baik dan tidak baik dengan memainkan peran dalam metode sosio-drama, anak memerankan karakter yang baik atau yang jahat agar anak terekam 
diingatannya mana yang sifat yang baik dan yang buruk. Hal ini menunjukan bahwa guru menerapkan cara yang sesuai dengan cara belajar anak, karena selain cara belajar anak dengan mengamati langsung alangkah baiknya kegiatan pembelajaran dapat dilakukan anak seperti bermain peran dalam metode sosio-drama tersebut. Cara agar anak bisa berpikir dapat membedakan mana sifat baik dan mana sifat buruk sering juga dengan memberi nasehat ketika didalam kelas. Hal ini menunjukan para guru untuk bisa memahamkan anak agar bisa mengerti tentang sifat-sifat baik selain dengan cara pengamatan objek dan melakukan langsung kegiatan juga dilengkapi dengan cara pemberian nasehat, karena karakter anak berbedabeda, ada yang suka belajar mengamati, suka belajar melakukan langsung dan ada juga efektif dinasehati. Ketiga cara ini saling diperlukan dan melengkapi agar anak bisa berpikir dan membedakan untuk berbuat mana sifat yang baik dan mana sifat yang tidak baik.

4) Guru Membuat Anak Berpikir Tentang Toleransi Beragama

Cara membuat anak bisa berpikir dalam artian mengerti dengan sifat toleransi beragama dengan sesama temannya yang berbeda agama yaitu guru memberikan penjelasan tentang mengapa harus berbeda dan dalam perbedaan itu harus saling menghargai dan tetap saling berteman. Cara lain membuat anak bisa mengerti dengan toleransi bergama dengan yaitu dengan penjelelasan kejadian perbedaan ajaran pola hidup beragama,. Hal ini menunjukan anak sangat peka terhadap perbedaan yang terjadi terhadap temannya dalam kegiatan pola hidup sehari-hari yang dilakukan anak bersama teman-temannya. Temuan di atas memperkuat hasil penelitian Zaini (2010) menyatakan bahwa cara untuk menanamkan sifat toleransi beragama kepada anak usia dini dengan cara anak dikenalkan berbagai macam hari-hari besar peringatan semua agama. Kemudian Zaini (2010) juga menyatakan bahwa dalam menanamkan nilai-nilai toleransi kepada anak harus terlebih dahulu para guru mempunyai pemahaman yang sama dalam menentukan strategi pembelajaran agar agar memiliki perspektif yang sama dan memiliki kebulatan tekad yang tegas dalam rangka menguatkan penanaman nilai-nilai toleransi pada anak- anak usia dini. Cara berikutnya dalam memahamkan anak tentang sifat toleransi antar agama ialah dengan kegiatan karyawisata, yaitu anak-anak dibawa ketempat miniatur ruangan yang isinya menggambarkan tempat ibadah berbagai agama. Temuan ini memperkuat hasil penelitian Zaini (2010) bahwa cara memberikan pemahaman toleransi dalam perbedaan agama diantar anak yang beragam agama dengan cara mengenalkan dan berkunjung ke tempattempat ibadah Seperti Masjid Pesantren untuk Umat Islam, Vihara untuk Umat Budha, Gereja untuk Umat Kresten, Biara untuk Umat Katolik, Pure untuk Umat Hindu dan Klenteng untuk Umat Konghucu dan sebaginya. Temuan di atas juga mendukung hasil penelitian Faizin (2016) bahwa strategi dalam menanamkan nilai-nilai toleransi beragama bisa dilakukan di luar kelas dengan melakukan karyawisata untuk mengamati objek diluar sekolah. Dalam strategi pembelajaran sikap atau moral ada aliran yang menganggap bahwa strategi dalam menanamkan aspek sikap kepada anak melalui perkembangan tingkat kognitif. Strategi ini dinamakan dengan strategi pembelajaran apektif dengan pengembangan kognitif. Strategi ini digagas oleh seoarang pakar 
psokologi perkembangan yaitu Kohlberg. Teori strategi pembelajaran sikap dengan pengembangan kognitif ini banyak diilhami oleh pemikiran Jhon Dewey dan Piaget yang berpendapat bahwa berdasarkan proses dari restrukturisasi kognitif yang berlangsur secara bertahap sesuai dengan tumbuh dan kembang manusia itu sendiri. Menurut Kohlberg, moral manusia itu berkembang melalui 3 tingkatan, yaitu prakonvensional, konvensional dan pascakonvensional. Tetapi tingkatan yang sesuai dengan anak usia dini secara umur ialah tingkat prakonpensional.

Penalaran prakonvensional adalah tingkat terendah dari penalaran moral, pada tingkat ini baik dan buruk diinterpretasikan melalui reward (imbalan) dan punishment (hukuman) eksternal. Tahap pertama yaitu moralitas heteronom, pada tingkat ini anak berorientasi pada kepatuhan dan hukuman, anak berpikir bahwa mereka harus patuh dan takut terhadap hukuman. Moralitas dari suatu tindakan dinilai atas dasar akibat fisiknya. Contoh: "bersalah dicubit". Kakak membuat adik menangis, maka ibu memukul tangan kakak (dalam batas-batas tertentu). Tahap kedua yaitu moralitas individualism, pada tingkat ini anak berpikir bahwa mementingkan diri sendiri adalah hal yang benar dan hal ini juga berlaku untuk orang lain. Karena itu, anak berpikir apapun yang mereka lakukan harus mendapatkan imbalan atau pertukaran yang setara. Jika ia berbuat baik, maka orang juga harus berbuat baik terhadap dirinya, anak menyesuaikan terhadap harapan sosial untuk memperoleh penghargaan. Contoh: berbuat benar akan dipuji "pintar sekali" (Ormord, 2000: 371).

Menurut Piaget anak berpikir tentang moralitas dalam 2 cara/tahap, yaitu cara heteronomous (usia 4-7 tahun) di mana anak menganggap keadilan dan aturan sebagai sifat-sifat (lingkungan) yang tidak berubah dan lepas dari kendali manusia, dan cara autonomous (usia 10 tahun keatas) di mana anak sudah menyadari bahwa aturan-aturan dan hukum itu diciptakan oleh manusia (Otib, 2008: 2.12). Cara guru agar anak bisa bicara atau menanggapi tentang toleransi dalam beragama pada saat pembelajaran dengan motode cerita. Dalam kegiatan cerita ini guru menceritakan tentang kisah-kisah yang membuat anak menanggapi secara rujukan ajaran agama, misalnya ada kejadian pada saat guru bercerita tentang perilaku kehidupan binatang, guru menceritakan berbagai macam binatang diantara guru menyebut perilaku binatang ayam, bebek, kucing kemudian samapai guru menyebutkan binatang babi dengan cerita sifatnya, maka ada anak yang menanggapi atau bersuara, bahwa binatang babi itu haram dimakan. Tetapi anak lain juga menaggapi, ia mengatakan bahwa daging babi itu rasanya enak. Setelah itu, gurunya baru menanggapi dengan memberikan penjelsan, bahwa binatang babi itu betul hukumnya haram dimakan bagi yang beragama Islam, tetapi bagi anak yang selain agama Islam ada yang boleh memakan binatang babi. Hal ini menunjukkan bahwa para guru mempunyai cara yang tepat dalam menstimulasi aspek pengembangan bahasa anak dalam memperhatikan, menyimak agar anak terbiasa berbicara, menanggapi dan membahas tentang perbedaan toleransi beragama dengan cara membedakan pola kehidudapan ajaran antara satu agama dengan agama yang lain.Temuan dia atas mendukung hasil penelitian Murdiono (2010) bahwa dalam menanamkan moral atau sifat baik kepada anak metode yang paling sering digunakan adalah bercerita dan pembiasaan. Karena dapat berpengaruh 
kepada perubahan perilaku anak dari yang tidak baik menjadi baik.

5) Guru Membuat Anak Merasakan Manfaat Sifat Toleransi

Cara membuat anak agar bisa merasakan manfaat bersikap dan berperilaku toleransi dengan teman yang berbeda agama di PAUD Widya Dharma adalah dengan dibiasakannya berbagi makanan apabila punya makanan, saling meminjami mainan kepada teman dan bersama-sama bermain tanpa membedakan agamanya. Tertanamnya rasa manfaat sifat toleransi beragama pada anak ini adalah saling mengingatkan apabila temannya melanggar ajaran agamanya. Hal saling mengingatkan ini biasanya pada momentum berdo'a, karena setiap anak berbeda-beda sikap berdo'anya. Apabila ada anak yang salah melakukan sikap berdo'a, misalnya katholik saat berdo'a tidak pejam mata, maka anak agama yang lain menegurnya, ataupun anak agama Islam yang ikut sikap berdo'a menggenggam tangan, maka anak yang lain menegurnya. Hal saling mengingatkan juga terjadi pada saat makan bersama, anak sudah saling mengingatkan kepada temannya yang agama islam tidak boleh makan daging babi, kalau temannya yang beragama Kristen boleh makan daging babi, temannya yang beragama budha tidak boleh makan makanan vegetarian dan hal lainnya yang mengandung perbedaan ajaran agama. Hal ini menunjukkan bahwa manfaat tolernasi beragama pada anak akan berdampak pada kehidupan nyata pada pola hidup anak dengan temannya dengan saling menegur dan mengingatkan apabila ada diantara temannya yang melakukan yang bukan atau dilarang dalam ajaran agamanya masing-masing. Temuan tersebut menguatkan hasil penelitian Faiqoh (2015) menyatakan bahwa anak usia dini yang dibiasakan untuk saling menghargai dan menghormati perbedaan diantara teman-temannya. Maka anak akan menerima perbedaan ntuk memiliki kepedulian sosial yang tinggi terhadap orang disekitarnya. Menurut Sumaatmatdja (2012: 9) mengemukakan bahwa penanaman sifat dan perilaku toleransi dapat dilakukan dengan 3 (tiga) pendekatan, yaitu (1) Perorangan (personal approach). (2) Pendekatan kelompok (interpersonal approach). (3) Pendekatan klasikal (classical approach). Sedangkan metode yang digunakan pada ranah implementasi bisa menggunakan metode cerita, ceramah, permainan simulasi, tanyajawab, diskusi, dan tugas mandiri. Toleransi menjadi sangat penting bagi keberlangsungan interaksi pertemanan sosial anak khususnya pada anak usia dini, karena anak usia dini sangat senang berteman (sosial). Oleh karena itu, penanaman toleransi terhadap anak menjadi hal yang penting di dalam proses pendidikan di sekolah. Hal ini senada dengan pendapat Haricahyono (1998: 203) bahwa tujuan pengembangan sikap toleransi dikalangan anak-anak di sekolah merupakan sebagai wahana latihan agar anak dapat berperilaku toleransi secara luas terhadap lingkungan disekitarnya.

\section{SIMPULAN}

Strategi penanaman toleransi beragama pada anak usia dini di PAUD Widya Dharma melalui lima kegiatan, yaitu:

1. Guru mengenalkan sifat-sifat baik dengan anak melalui cara pembiasaan, nasehat kejadian insidentil dan penjelasan.

2. Guru mengenalkan sifat toleransi beragama dengan anak melalui cara pembiasaan dan pemberian nasehat. 
3. Guru membuat anak agar bisa berpikir atau memahami sifat-sifat baik dengan cara pengamatan, bermain peran dan nasehat.

4. Guru membuat anak agar bisa berpikir atau memahami tentang toleransi melalui pemberian penjelasan, karyawisata dan penjelasan kejadian insidentil.

5. Cara membuat anak agar bisa merasakan manfaat sifat toleransi beragama melalui cara pembiasaan dan saling mengingatkan

\section{REFERENSI}

Al-Bukhari. (2011). Ensiklopedia Hadits: Shahih al-Bukhori 1. Jakarta: Almahira.

Azwar, S. (2010). Metode Penelitian. Yogyakarta: Pustaka Pelajar.

Cheppy, H. (1995). Dimensi-Dimensi Pendidikan Moral. Semarang: IKIP Press.

Depdikbud. (2003). Kamus Besar Bahasa Indonensia. Jakarta: Balai Pustaka.

DIKMAS, D. J. (2015). Pedoman Penanaman Sikap PAUD. Jakarta: Kementerian Pendidikan dan Kebudayaan RI.

Faiqaoh, N. (2015). Implementasi Pendidikan Berbasis Multikultural Sebagai Upaya Penanaman Nilai Karakter Kejujuran, Toleransi dan Cinta Damai. Semarang: Universitas Negeri Semarang.

Faizin , A. (2016). Strategi Pengamalan Nilai-Nilai Toleransi Beragama pada Siswa Melalui Binaan Rohani. Malang: UIN Maulana Malik Ibrahim.
Hartoyo, B. (2004). Konsep Dasar Pendidikan Anak Usia Dini. Jawa Tengah: BPPLSP Regional III.

Kementerian-Agama. (2010). Al-Qur'an Terjemah. Tanggerang: Panca Cemerlang.

Kutsianto. (2014). Metode Pembiasaan Sebagai Media Pembentukan Karakter Anak. Yogyakarta: UIN Sunan Kalijaga.

Mansur. (2011). Pendidikan Anak Usia Dini. Yogyakarta: Pustaka Pelajar.

Miles, M. B., \& A, M. H. (2005). Qualitative Data Analysis. Jakarta: UI Press.

Moleong, L. (2002). Metode Penelitian Kualitatif. Bandung: Remaja Rosdakarya.

Murdiono, M. (2015). Metode Penanaman Nilai Moral untuk AUD. Yogyakarta: Universitas Negeri Yogyakarta.

Ormord, J. (2000). Educational Psycologi. New Jarsey: Merill Prentice Hall Inc.

Otib , H. S. (2008). Metode Pengembangan Moral dan NilaiNilai Agama. Jakarta: Universitas Terbuka.

Permendikbud. (2014). Kurikulum 2013 Anak Usia Dini. jakarta: Kementerian Pendidikan dan Kebudayaan RI.

Rini, C. D. (2015). Peran Guru Agama dalam Meningkatkan Kerukunan Siswa Antar Agama. Malang: UIN Maulana Malik Ibrahim.

S, Nasution. (2006). Metodologi Research (Penelitian Ilmiah). Jakarta: Bumi Aksara. 
Santi, S. (2014). Upaya Guru Menumbuhkan Sikap Toleransi bagi AUD. Pontianak: UNTAN.

Shihab, Q. (1996). Membumikan AlQur'an. Bandung: Mizan.

Sumaatmatdja, N. (1998). Manusia dalam Konteks Sosial, Budaya, dan Lingkungan Hidup. Bandung: Alfabeta.

Undang-Undang. (1965). Pencegahan penyalahgunaan dan/atau Penodaan Agama. Jakarta: DPR RI.

Undang-Undang. (2003). Sistem Pendidikan Nasional. Jakarta: DPR RI.

Wati, W. P. (2015). Peran Guru PAI dalam Penanaman Nilai-Nilai Toleransi antar Umat Beragama. Yogyakarta: UIN Sunan kalijaga.

Yaqin, A. (2005). Pendidikan Multikultural. Yogyakarta: Pilar Media.

Yuliasari, N., Thamrin, M., \& Ali, M. (2015). Strategi Pengembangan Moral dan Agama di TK. Pontianak: UNTAN.

Zaini. (2010). Penguatan Pendidikan Toleransi Sejak Usia Dini (Menanamkan Nilai-nilai Toleransi dalam Pluralisme Beragama pada Pendidikan Anak Usia Dini (PAUD) . Toleransi Media Ilmiah Komunikasi Ummat Beragama, Volume 2 No. 1.

Zaman , B. (2008). Media dan Sumber Belajar TK. Jakarta: Universitas Terbuka. 